for conservation globally

Threatened

通
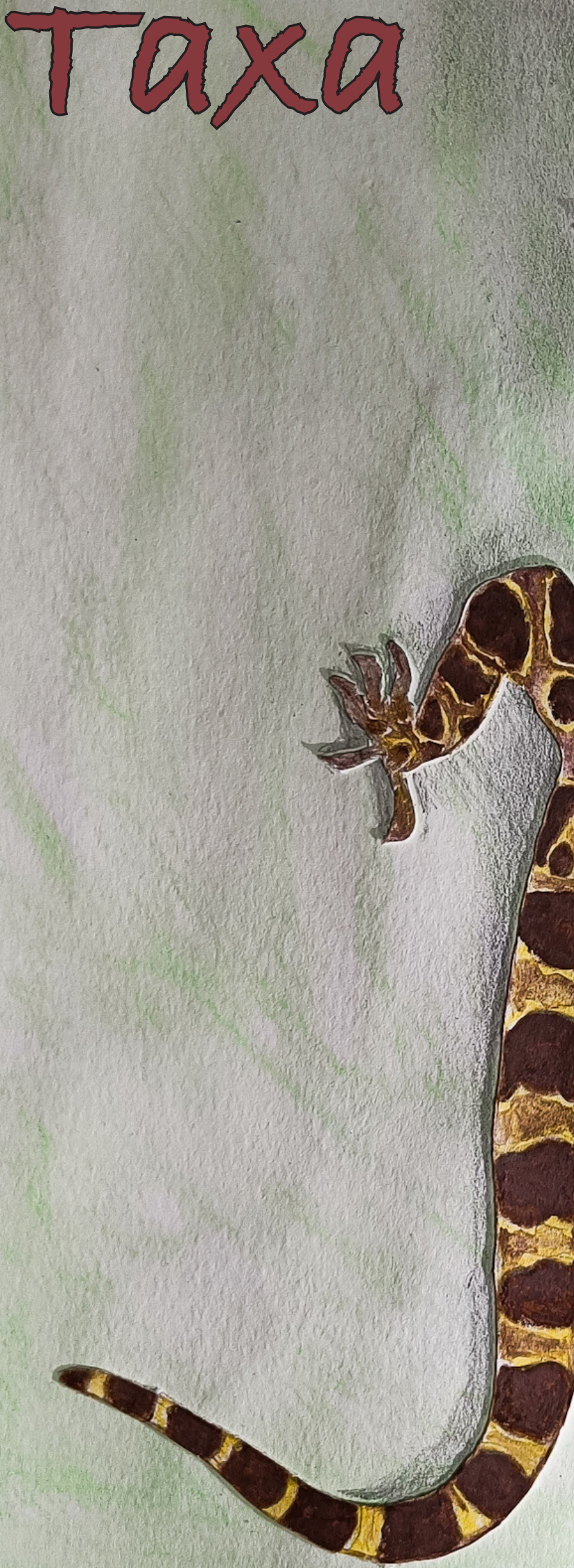

Open Access

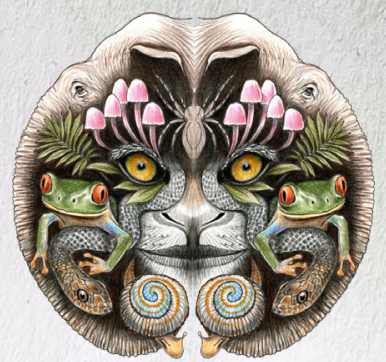

$10.1160 \mathrm{~g} / \mathrm{j}$ ott.2022.14.1.20311-20538 wWw.threatenedtaxa.org

26 January 2022 (Online \& Print) 14(1): 20311-20538 ISSN0974-7907 (Online) ISSN 0974-7893 (Print) 


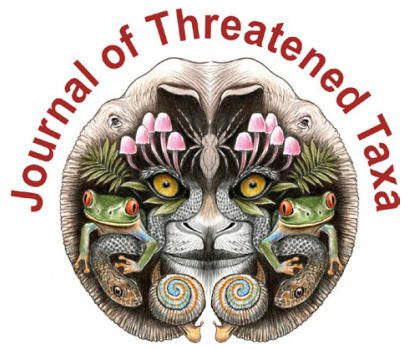

ISSN 0974-7907 (Online); ISSN $0974-7893$ (Print)

Publisher

Host

Wildlife Information Liaison Development Society

www.wild.zooreach.org

Zoo Outreach Organization www.zooreach.org

No. 12, Thiruvannamalai Nagar, Saravanampatti - Kalapatti Road, Saravanampatti, Coimbatore, Tamil Nadu 641035, India

Ph: +91 9385339863 | www.threatenedtaxa.org

Email: sanjay@threatenedtaxa.org

EDITORS

\section{Founder \& Chief Editor}

Dr. Sanjay Molur

Wildlife Information Liaison Development (WILD) Society \& Zoo Outreach Organization (ZOO),

12 Thiruvannamalai Nagar, Saravanampatti, Coimbatore, Tamil Nadu 641035, India

\section{Deputy Chief Editor}

Dr. Neelesh Dahanukar

Noida, Uttar Pradesh, India

\section{Managing Editor}

Mr. B. Ravichandran, WILD/ZOO, Coimbatore, India

\section{Associate Editors}

Dr. Mandar Paingankar, Government Science College Gadchiroli, Maharashtra 442605, India

Dr. Ulrike Streicher, Wildlife Veterinarian, Eugene, Oregon, USA

Ms. Priyanka Iyer, ZOO/WILD, Coimbatore, Tamil Nadu 641035, India

Dr. B.A. Daniel, ZOO/WILD, Coimbatore, Tamil Nadu 641035, India

\section{Editorial Board}

Dr. Russel Mittermeier

Executive Vice Chair, Conservation International, Arlington, Virginia 22202, USA

\section{Prof. Mewa Singh Ph.D., FASc, FNA, FNASc, FNAPsy}

Ramanna Fellow and Life-Long Distinguished Professor, Biopsychology Laboratory, and Institute of Excellence, University of Mysore, Mysuru, Karnataka 570006, India; Honorary Professor, Jawaharlal Nehru Centre for Advanced Scientific Research, Bangalore; and Adjunct Professor, National Institute of Advanced Studies, Bangalore

\section{Stephen D. Nash}

Scientific Illustrator, Conservation International, Dept. of Anatomical Sciences, Health Sciences Center, T-8, Room 045, Stony Brook University, Stony Brook, NY 11794-8081, USA

\section{Dr. Fred Pluthero}

Toronto, Canada

\section{Dr. Priya Davidar}

Sigur Nature Trust, Chadapatti, Mavinhalla PO, Nilgiris, Tamil Nadu 643223, India

\section{Dr. Martin Fisher}

Senior Associate Professor, Battcock Centre for Experimental Astrophysics, Cavendish

Laboratory, JJ Thomson Avenue, Cambridge CB3 OHE, UK

\section{Dr. John Fellowes}

Honorary Assistant Professor, The Kadoorie Institute, 8/F, T.T. Tsui Building, The University of Hong Kong, Pokfulam Road, Hong Kong

\section{Prof. Dr. Mirco Solé}

Universidade Estadual de Santa Cruz, Departamento de Ciências Biológicas, Vice-coordenado do Programa de Pós-Graduação em Zoologia, Rodovia Ilhéus/Itabuna, Km 16 (45662-000)

Salobrinho, Ilhéus - Bahia - Brasil

\section{Dr. Rajeev Raghavan}

Professor of Taxonomy, Kerala University of Fisheries \& Ocean Studies, Kochi, Kerala, India

\section{English Editors}

Mrs. Mira Bhojwani, Pune, India

Dr. Fred Pluthero, Toronto, Canad

Mr. P. Ilangovan, Chennai, India

Web Development

Mrs. Latha G. Ravikumar, ZOO/WILD, Coimbatore, India

\section{Typesetting}

Mr. Arul Jagadish, ZOO, Coimbatore, India

Mrs. Radhika, ZOO, Coimbatore, India

Mrs. Geetha, ZOO, Coimbatore India
Fundraising/Communications

Mrs. Payal B. Molur, Coimbatore, India

Subject Editors 2018-2020

Fungi

Dr. B. Shivaraju, Bengaluru, Karnataka, India

Dr. R.K. Verma, Tropical Forest Research Institute, Jabalpur, India

Dr. Vatsavaya S. Raju, Kakatiay University, Warangal, Andhra Pradesh, India

Dr. M. Krishnappa, Jnana Sahyadri, Kuvempu University, Shimoga, Karnataka, India

Dr. K.R. Sridhar, Mangalore University, Mangalagangotri, Mangalore, Karnataka, India

Dr. Gunjan Biswas, Vidyasagar University, Midnapore, West Bengal, India

\section{Plants}

Dr. G.P. Sinha, Botanical Survey of India, Allahabad, India

Dr. N.P. Balakrishnan, Ret. Joint Director, BSI, Coimbatore, India

Dr. Shonil Bhagwat, Open University and University of Oxford, UK

Prof. D.J. Bhat, Retd. Professor, Goa University, Goa, India

Dr. Ferdinando Boero, Università del Salento, Lecce, Italy

Dr. Dale R. Calder, Royal Ontaro Museum, Toronto, Ontario, Canada

Dr. Cleofas Cervancia, Univ. of Philippines Los Baños College Laguna, Philippines

Dr. F.B. Vincent Florens, University of Mauritius, Mauritius

Dr. Merlin Franco, Curtin University, Malaysia

Dr. V. Irudayaraj, St. Xavier's College, Palayamkottai, Tamil Nadu, India

Dr. B.S. Kholia, Botanical Survey of India, Gangtok, Sikkim, India

Dr. Pankaj Kumar, Kadoorie Farm and Botanic Garden Corporation, Hong Kong S.A.R., China

Dr. V. Sampath Kumar, Botanical Survey of India, Howrah, West Bengal, India

Dr. A.J. Solomon Raju, Andhra University, Visakhapatnam, India

Dr. Vijayasankar Raman, University of Mississippi, USA

Dr. B. Ravi Prasad Rao, Sri Krishnadevaraya University, Anantpur, India

Dr. K. Ravikumar, FRLHT, Bengaluru, Karnataka, India

Dr. Aparna Watve, Pune, Maharashtra, India

Dr. Qiang Liu, Xishuangbanna Tropical Botanical Garden, Yunnan, China

Dr. Noor Azhar Mohamed Shazili, Universiti Malaysia Terengganu, Kuala Terengganu, Malaysia

Dr. M.K. Vasudeva Rao, Shiv Ranjani Housing Society, Pune, Maharashtra, India

Prof. A.J. Solomon Raju, Andhra University, Visakhapatnam, India

Dr. Mandar Datar, Agharkar Research Institute, Pune, Maharashtra, India

Dr. M.K. Janarthanam, Goa University, Goa, India

Dr. K. Karthigeyan, Botanical Survey of India, India

Dr. Errol Vela, University of Montpellier, Montpellier, France

Dr. P. Lakshminarasimhan, Botanical Survey of India, Howrah, India

Dr. Larry R. Noblick, Montgomery Botanical Center, Miami, USA

Dr. K. Haridasan, Pallavur, Palakkad District, Kerala, India

Dr. Analinda Manila-Fajard, University of the Philippines Los Banos, Laguna, Philippines

Dr. P.A. Sinu, Central University of Kerala, Kasaragod, Kerala, India

Dr. Afroz Alam, Banasthali Vidyapith (accredited A grade by NAAC), Rajasthan, India

Dr. K.P. Rajesh, Zamorin's Guruvayurappan College, GA College PO, Kozhikode, Kerala, India

Dr. David E. Boufford, Harvard University Herbaria, Cambridge, MA 02138-2020, USA

Dr. Ritesh Kumar Choudhary, Agharkar Research Institute, Pune, Maharashtra, India

Dr. Navendu Page, Wildlife Institute of India, Chandrabani, Dehradun, Uttarakhand, India

\section{Invertebrates}

Dr. R.K. Avasthi, Rohtak University, Haryana, India

Dr. D.B. Bastawade, Maharashtra, India

Dr. Partha Pratim Bhattacharjee, Tripura University, Suryamaninagar, India

Dr. Kailash Chandra, Zoological Survey of India, Jabalpur, Madhya Pradesh, India

Dr. Ansie Dippenaar-Schoeman, University of Pretoria, Queenswood, South Africa

Dr. Rory Dow, National Museum of natural History Naturalis, The Netherlands

Dr. Brian Fisher, California Academy of Sciences, USA

Dr. Richard Gallon, llandudno, North Wales, LL30 1UP

Dr. Hemant V. Ghate, Modern College, Pune, India

Dr. M. Monwar Hossain, Jahangirnagar University, Dhaka, Bangladesh

Mr. Jatishwor Singh Irungbam, Biology Centre CAS, Branišovská, Czech Republic.

Dr. Ian J. Kitching, Natural History Museum, Cromwell Road, UK

Dr. George Mathew, Kerala Forest Research Institute, Peechi, India

For Focus, Scope, Aims, and Policies, visit https://threatenedtaxa.org/index.php/JoTT/aims_scope
For Article Submission Guidelines, visit https://threatenedtaxa.org/index.php/JoTT/about/submissions
For Policies against Scientific Misconduct, visit https://threatenedtaxa.org/index.php/JoTT/policies_various

continued on the back inside cover 


\title{
Estimating the completeness of orchid checklists and atlases: a case study from southern Italy
}

\author{
Antonio Croce (D) \\ GIROS (Gruppo Italiano per la ricerca sulle Orchidee Spontanee- Italian Group for the Research on Wild Orchids) \\ Via Chiesa - Tuoro, 44 - 81057 Teano, Caserta, Italy. \\ antocrx@gmail.com
}

\begin{abstract}
Checklists and atlases are important tools for knowledge of the biodiversity of a geographic unit. Nevertheless, they often suffer from bias due to preferential sampling. It is important to assess the level of completeness of the data collected during such research to allow comparison of the biodiversity of different areas, or to use them for macroecology, biogeography or conservation purposes. This assessment is not trivial, especially when information from heterogeneous sources is used (e.g., herbaria specimens, field observations, literature data). The author suggests some simple methods to assess the completeness of floristic database and to represent the distribution of the completeness at a scale level appropriate to the size of the studied area or, on another hand, to the precision level of the available data. Such information is useful to direct the surveys identifying less explored areas or habitats and thereby correcting the sampling biases. Adding information about sampling effort or completeness could be very useful to make floristic research more objective.
\end{abstract}

Keywords: European orchids, floristic studies, sampling effort, species richness estimators, completeness, citizen science.

Riassunto: le checklist e gli atlanti floristici sono strumenti importantissimi per la conoscenza della biodiversità. Tuttavia essi sono realizzati senza un design sperimentale e sono soggetti a bias dovuto soprattutto al campionamento preferenziale. E' comunque importante, soprattutto quando questi studi si basano su informazioni derivanti da fonti eterogenee (campioni d'erbario, osservazioni in campo, dati bibliografici, ecc.) valutare il loro grado di completezza per poter confrontare la biodiversità di diverse aree geografiche o per eseguire analisi macroecologiche, biogeografiche e per la valutazione dello stato di conservazione. L'autore propone alcuni semplici metodi per stimare l'esaustività dei dati floristici, rappresentare la distribuzione della completezza a scale adeguate da una parte alla dimensione dell'area oggetto di studio e dall'altra al livello di precisione dei dati a disposizione. Tali informazioni sono utili anche per orientare le ricerche nel territorio, individuando aree o habitat meno esplorati e correggendo i bias di campionamento. L'aggiunta di informazioni sullo sforzo di campionamento e la completezza delle ricerche può essere utile a conferire agli studi floristici di base una maggiore oggettività.

Citation: Croce, A. (2022). Estimating the completeness of orchid checklists and atlases: a case study from southern Italy. Journal of Threatened Taxa 14(1): 20311-20322. https://doi.org/10.11609/jott.6664.14.1.20311-20322

Copyright: (C Croce 2022. Creative Commons Attribution 4.0 International License. JoTT allows unrestricted use, reproduction, and distribution of this article in any medium by providing adequate credit to the author(s) and the source of publication.

Funding: None.

Competing interests: The author declares no competing interests.

Author details: ANTONIO CROCE earned a PhD in Applied Biology from the University of Naples "Federico II" in 2007 and he has worked as a research fellow or independent researcher on plant biodiversity and conservation, with a focus on Mediterranean orchids. He is currently a high school Science teacher and a member of GIROS, the Italian Group for the Research on Wild Orchids.

Acknowledgements: I would like to thank Prof. Giovanni Scopece, Department of Biology, University of Naples “Federico II", for his suggestions and encouragement. I would also thank an anonymous reviewer for her/his valuable comments. 


\section{INTRODUCTION}

Floristic inventories or check lists and atlases are important tools for assessing biodiversity and addressing its conservation (Vallet et al. 2012). They are often the result of careful and time-consuming researches conducted in specific geographic units, focused on vascular plants or on smaller taxonomic group such as Orchidaceae, one of the largest and most widespread family of flowering plants (Dressler 1981; WCSPF 2019). The presence and distribution of species of this family have been assessed at different scales as most of them are rare, threatened or endangered (Cribb et al. 2003). A checklist is a "card collection" aiming at listing all the taxa belonging to the studied taxonomic group and reporting whether they are observed, collected or reported in literature for a given area (e.g., Mathew \& George 2015; Aung et al. 2020; Popovich et al. 2020). The taxa are typically identified at species or subspecies level, some sites of growth are reported together with other information on the habitats, variety, rarity, ecology, chorology, systematic or taxonomic issues. Atlases are more focused on the geographic distribution of the taxa, instead. To be accomplished they require a field work aiming not only at listing all the different taxonomic entities, but also at detecting as more sites of growth as possible for each taxon. The result of such work is a checklist with cartographic references or distribution maps and, sometimes, their elaborations (e.g., Crain \& Fernández 2020; Efimov 2020). Due to the long time needed for exhaustive surveys, at a local scale this kind of research is increasingly carried out by non academics, the so called 'citizen scientists'. This is particularly true for the inventories and atlases of the European terrestrial orchids, often published in specialized journals (e.g., Galesi \& Lorenz 2010; Frangini et al. 2019; Katopodi \& Tsiftsis 2019; Marrero et al. 2019).

The huge amount of work, even when results in detailed distribution maps, almost never follows an experimental design, and currently data are affected by bias caused by a preferential sampling approach, e.g., data collector tends to sample protected areas or to collect more data along the roads (Croce \& Nazzaro 2017). Furthermore, none of the above mentioned floristic studies is usually provided with a clear reference to the sampling effort or to the level of completeness of the surveys. The absence of a repeatable background and of a standardized approach is not a trivial issue, as such collections of data are of great value for macroecology, ecology, biogeography or conservation research (Soberón et al. 2000, 2007; Rocchini et al. 2011; Weigelt et al. 2020).
In order to make inventories and atlases useful tools for biogeographical or ecological research it is thus necessary to take into account these issues and support floristic works with appropriate measures of the degree of uncertainty (Rocchini et al. 2011). In the same context, maps of floristic richness should be accompanied by maps of knowledge, "maps of ignorance" or maps of completeness. These can be realized considering that the number of species (namely the species richness) recorded in a given period and in a given area is partial and lower than the real number of species present (Gotelli \& Colwell 2011). The more the sample effort increases the more the number of observed species approaches the theoretical, real number of species. On the contrary, a sampling activity carried over a too long time could detect the species turnover (e.g., for habitat change due to socio-economic or ecological reasons or for climate changing) resulting in an overestimation of the number of species than the existing habitats could theoretically host in a given time. The real floristic richness and its distribution in an area can be estimated with different methods (Gotelli \& Colwell 2001; Vallet et al 2012). The most suitable for the kind of data recorded in the field by orchidologists is the use of 'sample based species rarefaction-curves' (Gotelli \& Colwell 2001). Given that the sampling order in an area is not important, data are resampled and curves are built. While the shape of accumulation curves depends upon the order in which the samples are considered, the rarefaction curves show smoother lines facilitating the comparison among entire datasets or subsets. A species rarefaction curve is plotted starting from the mean number of species of the smallest sample size. Then the mean number of species is calculated for all combinations of the next sample size (i.e., the mean number of species of two random samples, then three random samples, etc.).

This paper analyzes some typical aspects of local scale inventories and atlases hitherto neglected. Here, we propose simple approaches, accessible even for the non-academic, citizen scientists to answer the following specific questions:

i. How can the richness of a floristic database be assessed and how can different database be compared?

ii. Which richness estimator is more suitable for terrestrial European orchids, given its intrinsic difficulties of observation in field?

iii. When is the sampling of an area sufficiently complete?

iv. How can completeness maps be realised and how they can be useful to identify where to address further explorations? 


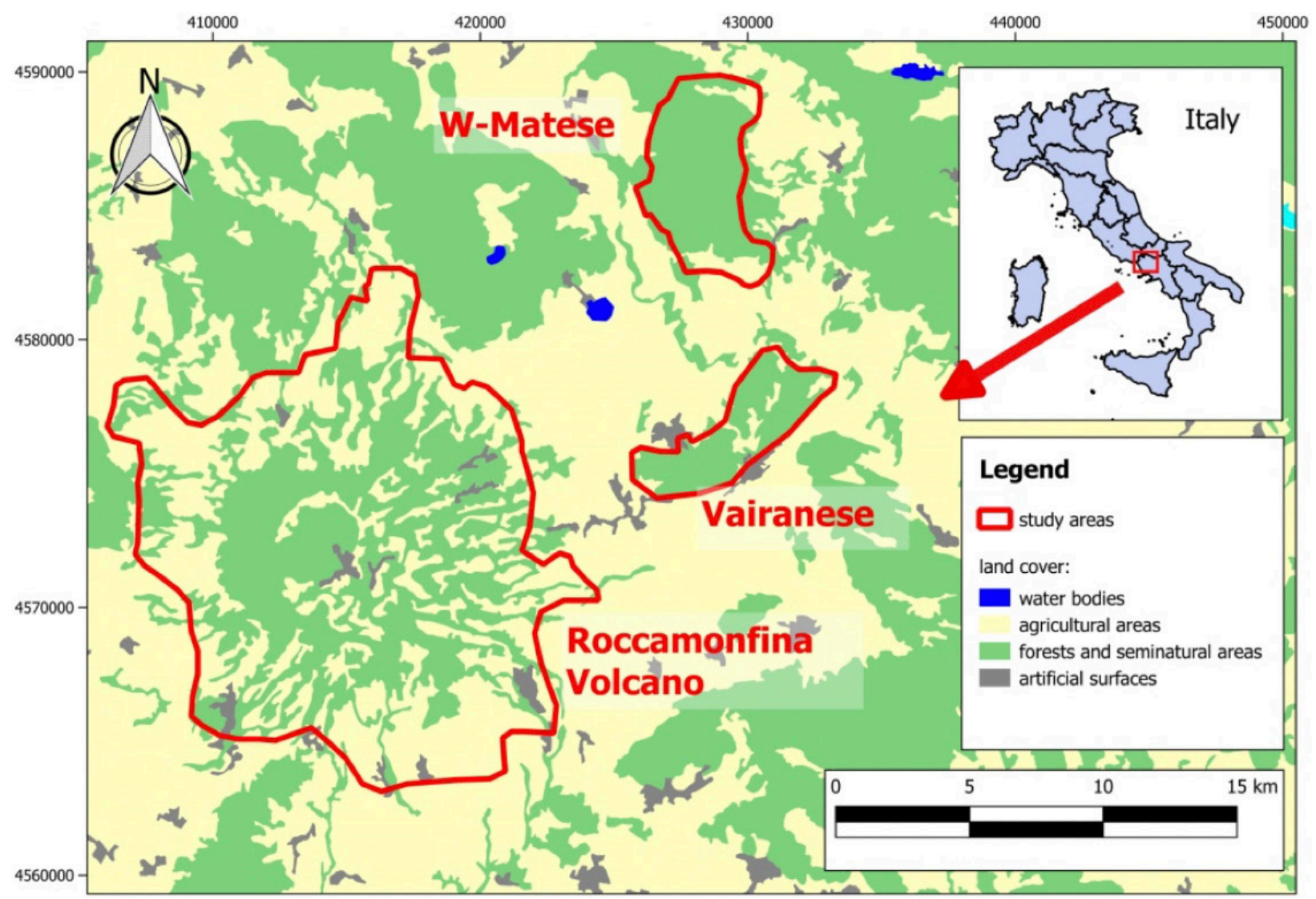

Figure 1. Location of the study areas (red lines) and land cover map. Coordinates are expressed as WGS84 UTM 33N (EPSG 32633).

\section{MATERIALS AND METHODS}

\section{Source of the data and study areas}

We used three datasets reporting the presence of orchids in three areas in southern Italy, in northern Campania region, (Figure 1; Table 1) about $50 \mathrm{~km}$ north of Naples and 150 south of Rome. The first dataset includes 3,046 records collected from 1996 to 2019 on the Roccamonfina volcano (Croce \& Nazzaro 2012 and following observations). It covers an area of about $210 \mathrm{~km}^{2}$ and lists 46 taxa (species and subspecies). The second dataset consists of 278 records collected from 2002 to 2005 on the little limestone mountain range of Vairano Patenora and Pietravairano municipalities (Croce 2012 and following observations), hereafter called "Vairanese". It covers an area of $17 \mathrm{~km}^{2}$ and lists 32 taxa. The third dataset consists of 305 records collected mainly in 2005 and then from 2013 to 2019 on the limestone mountain ranges of the western Matese area, hereafter called "W-Matese". It covers an area of $20 \mathrm{~km}^{2}$ and lists 33 taxa.

\section{Data collection}

Only the observations geolocated with a precision level lower than $100 \mathrm{~m}$ (punctual data according to Croce \& Nazzaro 2017) were included in the analysis. Nomenclature was revised and, when needed, standardised and hybrids were excluded from the analysis. To avoid the oversampling bias (i.e., a single population of plants sampled in different sampling units) the records have been clumped to represent the presence of the taxa in $100 \times 100 \mathrm{~m}$ squares, connected to the geographic grid of the used coordinates system (WGS 84 / UTM zone 33N, EPSG 32633). Each sampling unit (plot) is univocally identified, therefore, by the geographic position of the square and by the sampling date so that two sampling activities that took place in two different date but inside the same square have been considered as two different plots. In this way, I take into account the sampling effort in terms of time, very important for species requiring observations at different times to be correctly observed and identified. In the end I get, for each dataset, a matrix taxon $\times$ plot that I used for the elaborations and further analysis. 


\section{Data analysis}

To compare the three datasets in terms of sampling effort and observed specific richness $\left(\mathrm{S}_{\text {obs }}\right)$, I have mapped the specific richness for each area using a grid with $1 \mathrm{~km}^{2}$ resolution (i.e., $1 \times 1 \mathrm{~km}$ UTM cells) intersecting the study areas (i.e., the three geographic units as defined above) and calculating both the number of plots and the number of observed species in each cell. $A$ regression analysis between the number of plots and the number of species per each cell has been performed to correlate the sampling effort to the observed species richness and therefore to validate the density of plots as an indicator of the sampling effort. Then for each area I built a sample-based rarefaction curve using the plots as samples. The curves have been limited to the lower number of plots in the three datasets for a better comparison of the observed species richness and its pattern among the three studied areas. Being drawn with resampling statistical methods, the curves allow the calculation of the $95 \%$ confidence limits or the standard deviations.

Among the methods used to estimate the species richness of an area starting from presence-absence data, the most appropriate for floristic inventories and atlases is the relation between number of species and sampling effort (Vallet et al. 2012). This relation is investigated mainly using non parametric estimators, less sensitive to the sampling effort (Palmer 1990; Brose et al. 2003). Such indexes give an estimate of the species richness for a given geographic unit, based upon the considered sample and, therefore, upon its species assemblage. Once an estimate value is obtained, the completeness for each of the three datasets can be calculated by means of the completeness index proposed by Soberón et al. (2000). Such index (C) is expressed as a percentage value of the ratio between the number of observed species $\left(\mathrm{S}_{\mathrm{obs}}\right)$ and the number of estimated species $\left(\mathrm{S}_{\text {est }}\right)$ :

$\mathrm{C}=\mathrm{S}_{\mathrm{obs}} / \mathrm{S}_{\text {est }}$

The most used non parametric estimators for presence/absence data or incidence data are Jackknife, Chao, Bootstrap, and ICE (Gotelli \& Colwell 2011; Vallet et al. 2012). While the first of these indexes could represent a good compromise (Brose et al. 2003), several other authors prefer to compare more than one index (Martinez-Sanz et al. 2010; Bruno et al. 2012; GarciaMarquez et al. 2012; Vallet et al. 2012; Archer 2019). It is therefore noted that the Jackknife estimator gives higher values of estimated richness and, accordingly, lower completeness values than the Bootstrap estimator (Garcia-Marquez et al. 2012). Nevertheless, it is particularly effective in estimating the richness of small sample size (Hortal et al. 2006). Another very used estimator is Chao2 (Ugland et al. 2003; Chao \& Chiu 2016; Idohou et al. 2015; Asase \& Peterson 2016) that gives more emphasis to the presence of singletons species (i.e., present in only one plot of the set or subset) or doubletons (i.e., present in only two plots). Considered that many orchid species are locally rare and the number of rare species increases with decreasing the size of the sampled area, I calculated the completeness index (C) choosing as value of estimated richness $\left(\mathrm{S}_{\text {est }}\right)$ the maximum value between Chao2 $\left(\mathrm{S}_{\mathrm{Chao} 2}\right)$ and Jackknife1 $\left(S_{\text {jack1 }}\right)$ estimates. For each of the three study areas I calculated the total value of completeness (C) and the completeness of each cell of the $1 \mathrm{~km}^{2}$ UTM grid, using the plots as sampling units. Only for Roccamonfina area the completeness has been calculated also for each cell of a $4 \mathrm{~km}^{2}, 9 \mathrm{~km}^{2}, 16 \mathrm{~km}^{2}, 25 \mathrm{~km}^{2}$, and $36 \mathrm{~km}^{2}$ UTM grid intersecting the study area. Then I aggregated the data into $1 \times 1 \mathrm{~km}$ cells and the obtained taxon $\times$ cells matrix has been used to recalculate the estimated species richness and the completeness of each study area. This was intended to test the reliability of such atlases built mapping the presence of the species in grids with cells of $1 \mathrm{~km}^{2}$ or more, to estimate the species richness of the study areas. In order to test the estimators robustness when even larger sample units are used, the above mentioned aggregation method has been repeated using grids of $4 \mathrm{~km}^{2}, 9 \mathrm{~km}^{2}, 16 \mathrm{~km}^{2}, 25 \mathrm{~km}^{2}$, and $36 \mathrm{~km}^{2}$ cells, only for the larger area of Roccamonfina volcano. In other terms, I used increasing size cells as sampling units. Such cells size can be useful to analyse atlases produced with bibliographic data whose precise geolocation is not possible. The completeness of each cell, for all the grids of different cells size, has been classified into four levels: 0-25 \%, 25-50\%, 50-75\%, and 75-100\%. The cell with less than six plots have not been analysed and have been classified as "not evaluable" (n.e.). These limits have been set considering for all the datasets used an average number of five plot sampled in a day. According to the method used in Bruno et al. (2012), the cells with completeness $>65 \%$ have been considered sufficiently studied squares (SSS).

Once I knew the less explored cells, to which priority in the future research should be given, I could assess the level of completeness of our datasets among different habitats. So, I assigned a kind of vegetation to each plot on the basis of the collected field information and therefore I estimated the completeness of each vegetation type for each study area as explained above.

The cartographic elaborations have been performed by the software Qgis3 (QGIS Development Team 2019), 
the rarefaction curves and the calculation of the richness estimators have been produced by means of the software Estimates 8.20 (Colwell 2013) performing 1000 permutations. Statistical analyses have been performed using the software PAST (Hammer et al. 2001). All the used software is open source or free.

\section{RESULTS}

In Table 1 the data about the three study areas are reported, including the list of the taxa considered. The Roccamonfina area has the highest species richness, average number of records/plot and plot $/ \mathrm{km}^{2}$. Vairanese and $\mathrm{W}$-Matese show comparable values of the number of records/plot (higher values for W-Matese) and number of plots $/ \mathrm{km}^{2}$ (higher values for Vairanese). Nevertheless, the distribution of the number of plots (Figure 2a) and observed species richness (Figure $2 \mathrm{~b}$ ) in the $1 \mathrm{~km}^{2}$ cells is extremely heterogeneous with a very high standard deviation of the plots/cells ratio (6.9 for Roccamonfina, 6.5 for Vairanese and 5.9 for Matese areas). Such values underline a sampling effort not uniformly distributed in the studied areas.

The regression analysis (Figure 3 ) shows, for all the three areas, a statistically significant $(p<0.001)$ positive correlation between the number of plots and the number of species inside the $1 \mathrm{~km}^{2}$ cells. The two variables are statistically correlated according to the Kendall's tau test.

The rarefaction curves (Figure 4) indicate a similar pattern for all the three areas: limited to 121 plots, they show slight differences with a higher species richness for the W-Matese area (32.84 average observed species) followed by the Vairanese area (32 average observed species) and the Roccamonfina volcano (31.32 average observed species).

The total estimated floristic richness, computed using the plots as sampling units (Table 2) for each of the three areas, gives completeness values between 78.2\% (Vairanese) and 88.5\% (Roccamonfina). Using the $1 \mathrm{~km}^{2}$ cells as sampling units (Table 3 ), we get identical values for Roccamonfina area, a slightly higher value for Vairanese area and slightly lower for W-Matese area.

The completeness of the $1 \mathrm{~km}^{2}$ cells in the three areas (Figure 2c) is distributed in a similar way in the Roccamonfina and Vairanese areas (Table 4): the $35.6 \%$ and $33.3 \%$ of the $1 \mathrm{~km}^{2}$ cells, respectively, have a completeness higher than $65 \%$ and therefore are considered as Sufficiently Studied Squares (SSS). For the W-Matese area only the $25 \%$ of the $1 \mathrm{~km}^{2}$ cells are SSS. It is relevant, for each area, the great number of cells with data not allowing further elaborations ('n.e.' cells).

The estimated richness for the Roccamonfina area, calculated using sampling units of increasing size (Figure 5) shows a general stability of the two estimators chosen, always with higher values for Jackknife1 estimator (51.82-53.47) compared to Chao2 estimator (48.11-49.34). Both the estimators feature variations included within 1.65 unity, a value lower than the standard deviations calculated by the software. The completeness of the cells of increasing size, calculated for Roccamonfina area (Table 5) using the plots as sampling units, gives a gradual increase of the number of SSS, up to over $50 \%$ of the $9 \mathrm{~km}^{2}$ cells and $80 \%$ of the $36 \mathrm{~km}^{2}$ cells.

In Table 6 the observed and estimated species richness and the completeness of the different habitats using the plots as sampling units are reported. For the Roccamonfina area the completeness of the habitats is high except for agricultural environments. The chestnut orchards host the higher species richness (38 species, $82 \%$ of the whole area), followed by the open habitats such as meadows and shrublands (33 species). In the other study areas the completeness is relatively low for the broadleaved woodlands of Vairanese and open habitats of the W-Matese, indicating a still not adequate sampling for such habitats. For a better comparison of the species richness among the different habitats, considering that more than $70 \%$ of the plots are located inside chestnut orchards, the rarefaction curves were plotted for Roccamonfina habitats (Figure 6), limited to 100 plots. The richness curve rises in a steeper way in the chestnut orchards but it is overtaken by artificial habitats around 30 plots and by open habitats around 50 plots. The richness of broadleaved woodlands and chestnut coppices is always lower, as expected.

\section{DISCUSSION}

The higher species richness is correlated to the sampling effort, expressed as number of plots, as well as the ecological features of the areas and their extension. This parameter is known, in ecology as the species/area relationship (SAR - Preston 1962) and it could be used to compare and estimate species richness of floristic atlases only under certain conditions that, if disregarded impede its extrapolation (Vallet et al. 2012). The correlation analysis here performed confirms that the higher is the number of sampling units (plot) in an area, the higher will be the observed species richness. Comparing the richness of the three studied areas plotted by rarefaction curves, highlights that with the same sampling effort 


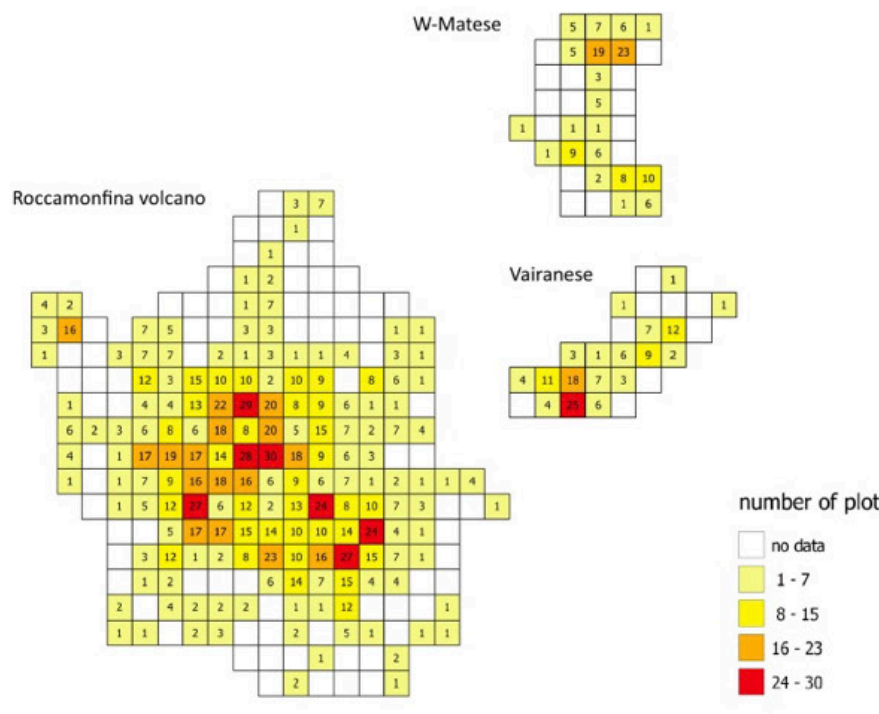

\section{a}
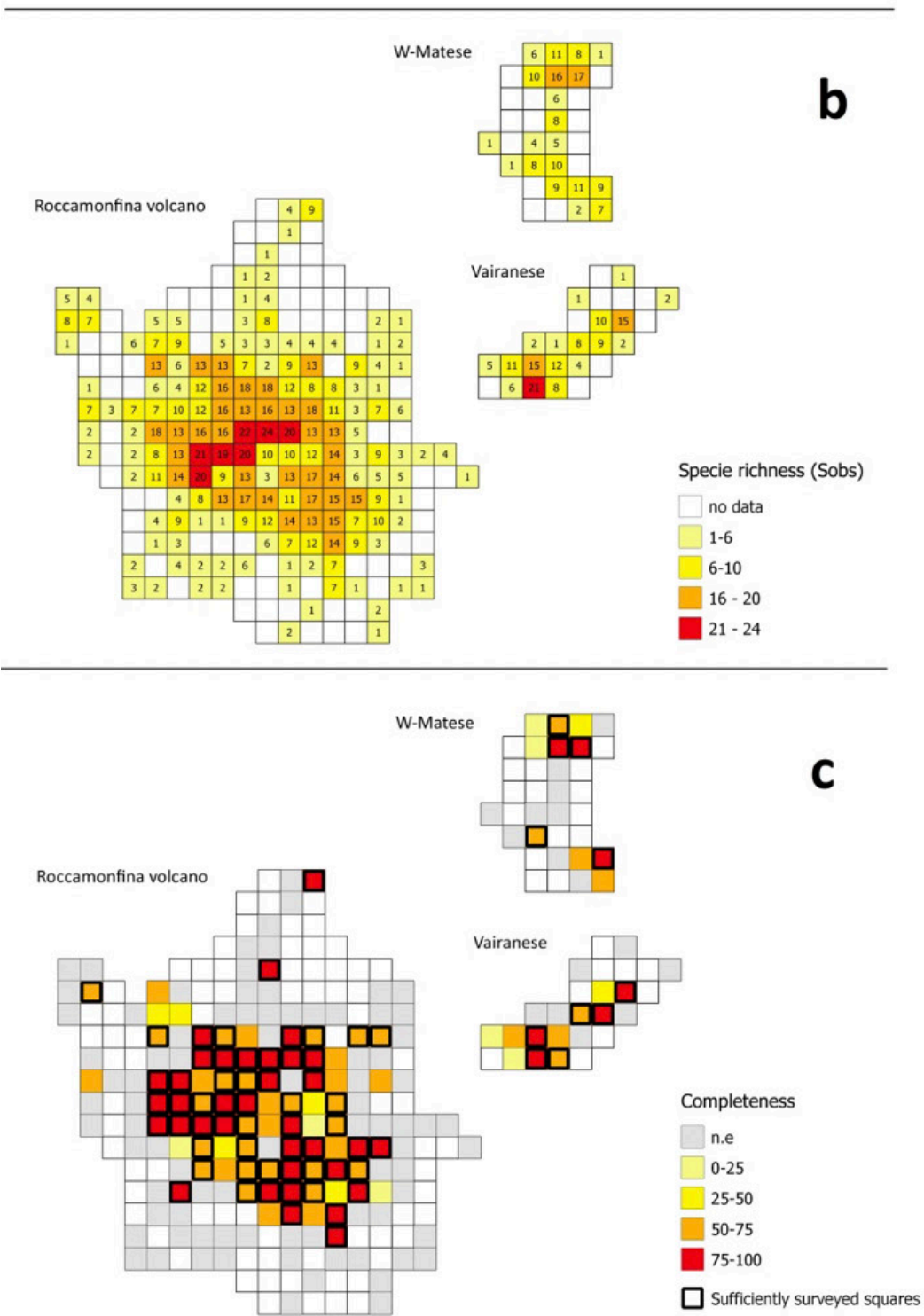

Figure 2. Distribution maps: $a-n u m b e r$ of plots | b-number of observed species | c-Completeness level, for the $1 \mathrm{~km}^{2}$ cells covering the three study areas. 
Table 1. Data of the three study areas and list of the taxa considered for the analysis.

\begin{tabular}{|c|c|c|c|}
\hline & Roccamonfina & Vairanese & W-Matese \\
\hline Sobs & 46 & 32 & 33 \\
\hline Area $\left(\mathrm{km}^{2}\right)$ & 210 & 18 & 20 \\
\hline $1 \mathrm{~km}^{2}$ cells & 163 & 18 & 20 \\
\hline altitude (min-max) & 150-1005 & $125-588$ & $150-811$ \\
\hline Number of Plots & 1184 & 121 & 124 \\
\hline Database-records & 3046 & 263 & 296 \\
\hline records/plot & 2.57 & 2.17 & 2.39 \\
\hline Plot/km² & 7.26 & 6.72 & 6.2 \\
\hline Anacamptis coriophora (L.) R.M.Bateman, Pridgeon \& M.W.Chase & $\mathrm{x}$ & $\mathrm{x}$ & $\mathrm{x}$ \\
\hline Anacamptis morio (L.) R.M.Bateman, Pridgeon \& M.W.Chase & $\mathrm{x}$ & $\mathrm{x}$ & $\mathrm{x}$ \\
\hline Anacamptis papilionacea (L.) R.M.Bateman, Pridgeon \& M.W.Chase & $\mathrm{x}$ & $\mathrm{x}$ & $\mathrm{x}$ \\
\hline Anacamptis pyramidalis (L.) Rich. & $\mathrm{x}$ & $\mathrm{x}$ & $\mathrm{x}$ \\
\hline Cephalanthera damasonium (Mill.) Druce & $\mathrm{x}$ & $\mathrm{x}$ & $\mathrm{x}$ \\
\hline Cephalanthera longifolia (L.) Fritsch & $\mathrm{x}$ & & $\mathrm{x}$ \\
\hline Cephalanthera rubra (L.) Rich. & $\mathrm{x}$ & & \\
\hline Dactylorhiza maculata (L.) Soó subsp. saccifera (Brongn.) Diklić & $\mathrm{x}$ & $\mathrm{x}$ & \\
\hline Dactylorhiza romana (Sebast.) Soó subsp. romana & $\mathrm{x}$ & $\mathrm{x}$ & \\
\hline Dactylorhiza sambucina (L.) Soó & $\mathrm{x}$ & & \\
\hline Epipactis exilis P.Delforge & $\mathrm{x}$ & & \\
\hline Epipactis helleborine (L.) Crantz subsp. helleborine & $\mathrm{x}$ & $\mathrm{x}$ & \\
\hline Epipactis microphylla (Ehrh.) Sw. & $\mathrm{x}$ & $\mathrm{x}$ & $\mathrm{x}$ \\
\hline Epipactis muelleri Godfery & $\mathrm{x}$ & $\mathrm{x}$ & \\
\hline Epipactis maricae (Croce, Bongiorni, De Vivo \& Fori) Presser \& S.Hertel & $\mathrm{x}$ & & \\
\hline Epipactis placentina Bongiorni \& Grünanger & $\mathrm{x}$ & & \\
\hline Gymnadenia conopsea (L.) R.Br. & $\mathrm{x}$ & & \\
\hline Himantoglossum adriaticum H.Baumann & $\mathrm{x}$ & & $\mathrm{x}$ \\
\hline Limodorum abortivum (L.) Sw. & $\mathrm{x}$ & $x$ & $\mathrm{x}$ \\
\hline Neotinea maculata (Desf.) Stearn & $\mathrm{x}$ & $\mathrm{x}$ & $\mathrm{x}$ \\
\hline Neotinea tridentata (Scop.) R.M.Bateman, Pridgeon \& M.W.Chase & $\mathrm{x}$ & $\mathrm{x}$ & $x$ \\
\hline Neottia nidus-avis (L.) Rich. & $x$ & & \\
\hline Neottia ovata (L.) Bluff \& Fingerh. & $\mathrm{x}$ & & \\
\hline Ophrys apifera Huds. & $\mathrm{x}$ & $\mathrm{x}$ & $x$ \\
\hline Ophrys argolica H.Fleischm. ex Vierh. subsp. crabronifera (Mauri) Faurh. & $\mathrm{x}$ & $\mathrm{x}$ & $\mathrm{x}$ \\
\hline Ophrys bertolonii Moretti subsp. bertolonii & $\mathrm{x}$ & $\mathrm{x}$ & $\mathrm{x}$ \\
\hline Ophrys bombyliflora Link & & & $x$ \\
\hline Ophrys exaltata Ten. subsp. montis-leonis (O.Danesch \& E.Danesch) Soca & $\mathrm{x}$ & & \\
\hline $\begin{array}{l}\text { Ophrys holosericea (Burnm.f.) Greuter subsp. gracilis (Büel, O.Danesch \& E.Danesch) } \\
\text { O.Danesch \& E.Danesch }\end{array}$ & & $\mathrm{x}$ & \\
\hline Ophrys holosericea (Burnm.f.) Greuter subsp. holosericea & $\mathrm{x}$ & $\mathrm{x}$ & $\mathrm{x}$ \\
\hline Ophrys incubacea Bianca & $\mathrm{x}$ & & \\
\hline Ophrys insectifera L. & & $\mathrm{x}$ & $x$ \\
\hline Ophrys lutea Cav. & $\mathrm{x}$ & $\mathrm{x}$ & $\mathrm{x}$ \\
\hline Ophrys promontorii O.Danesch \& E.Danesch & $\mathrm{x}$ & & $\mathrm{x}$ \\
\hline Ophrys sphegodes Mill. subsp. sphegodes & $\mathrm{x}$ & $\mathrm{x}$ & $\mathrm{x}$ \\
\hline Ophrys sphegodes Mill. subsp. minipassionis (Romolini \& Soca) Biagioli \& Grünanger & & & $x$ \\
\hline
\end{tabular}




\begin{tabular}{|c|c|c|c|}
\hline & Roccamonfina & Vairanese & W-Matese \\
\hline Ophrys tenthredinifera Willd. subsp. neglecta (Parl.) E.G.Camus & $x$ & & \\
\hline Orchis anthropophora (L.) All. & $x$ & $x$ & $x$ \\
\hline Orchis italica Poir. & $\mathrm{x}$ & $x$ & $x$ \\
\hline Orchis mascula (L.) subsp. mascula & $x$ & & $x$ \\
\hline Orchis pauciflora Ten. & & $x$ & $x$ \\
\hline Orchis provincialis Balb. ex Lam. \& DC. & $x$ & $x$ & $x$ \\
\hline Orchis purpurea Huds. & $x$ & $x$ & $x$ \\
\hline Orchis simia Lam. & $x$ & & $x$ \\
\hline Platanthera bifolia (L.) Rich. & $x$ & $x$ & \\
\hline Platanthera chlorantha (Custer) Rchb. & $x$ & $x$ & $x$ \\
\hline Serapias cordigera $\mathrm{L}$. & $x$ & $x$ & \\
\hline Serapias lingua $\mathrm{L}$. & $\mathrm{x}$ & & $x$ \\
\hline Serapias parviflora Parl. & $x$ & $x$ & $x$ \\
\hline Serapias vomeracea (Burm.f.) Briq. subsp. longipetala (Ten.) H.Baumann \& Künkele & $x$ & $x$ & $x$ \\
\hline Spiranthes spiralis (L.) Chevall. & $x$ & $x$ & $x$ \\
\hline
\end{tabular}

Table 2. Total completeness values for the three study areas using $100 \times 100 \mathrm{~m}$ plots as sampling units.

\begin{tabular}{|l|c|c|c|}
\hline & Roccamonfina & Vairanese & W-Matese \\
\hline $\begin{array}{l}\text { n. Plots (100 } \times \\
\mathbf{1 0 0} \mathbf{~ m})\end{array}$ & 1184 & 121 & 124 \\
\hline Sobs & 46 & 32 & 33 \\
\hline $\mathbf{S}_{\text {chao2 }}$ & 49 & 35.72 & 37.9 \\
\hline $\mathrm{S}_{\text {Jack1 }}$ & 51.99 & 40.93 & 39.94 \\
\hline Completeness \% & $\mathbf{8 8 . 5}$ & $\mathbf{7 8 . 2}$ & $\mathbf{8 2 . 6}$ \\
\hline
\end{tabular}

Table 4. Levels of completeness values of the $1 \mathbf{k m}^{2}$ cells, for the three study areas.

\begin{tabular}{|l|c|c|c|c|c|c|}
\hline & \multicolumn{2}{|c|}{ Roccamonfina } & \multicolumn{2}{c|}{ Vairanese } & \multicolumn{2}{c|}{ W-Matese } \\
\hline $\begin{array}{l}\text { Completeness } \\
\text { level \% }\end{array}$ & $\begin{array}{c}\mathrm{n} . \\
\text { cells }\end{array}$ & $\%$ & $\begin{array}{c}\mathrm{n} . \\
\text { cells }\end{array}$ & $\%$ & $\begin{array}{c}\mathrm{n} . \\
\text { cells }\end{array}$ & $\%$ \\
\hline n.e. & 84 & $\mathbf{5 1 . 5}$ & 7 & $\mathbf{3 8 . 9}$ & 9 & $\mathbf{4 5 . 0}$ \\
\hline $\mathbf{0 - 2 5}$ & 3 & $\mathbf{1 . 8}$ & 2 & $\mathbf{1 1 . 1}$ & 2 & $\mathbf{1 0 . 0}$ \\
\hline $\mathbf{2 5 - 5 0}$ & 5 & $\mathbf{3 . 1}$ & 1 & $\mathbf{5 . 6}$ & 1 & $\mathbf{5 . 0}$ \\
\hline $\mathbf{5 0 - 7 5}$ & 35 & $\mathbf{2 1 . 5}$ & 4 & $\mathbf{2 2 . 2}$ & 5 & $\mathbf{2 5 . 0}$ \\
\hline $\mathbf{7 5 - 1 0 0}$ & 36 & $\mathbf{2 2 . 1}$ & 4 & $\mathbf{2 2 . 2}$ & 3 & $\mathbf{1 5 . 0}$ \\
\hline Total & 163 & & 18 & & 20 & \\
\hline SSS & 58 & $\mathbf{3 5 . 6}$ & 6 & $\mathbf{3 3 . 3}$ & 5 & $\mathbf{2 5 . 0}$ \\
\hline
\end{tabular}

(i.e., the same number of plots), the richest area can host a relatively lower number of species than the less rich area. Nevertheless, such kind of analysis requires the same exhaustivity of the studies for each area. The overall completeness of the study areas gives values close to $90 \%$ and consistently above $70 \%$. Also, very
Table 3. Total completeness values for the three study areas using 1 $\mathrm{km}^{2}$ cells as sampling units.

\begin{tabular}{|l|c|c|c|}
\hline & Roccamonfina & Vairanese & W-Matese \\
\hline No. of $\mathbf{1} \mathbf{~ k m}^{2}$ cells & 163 & 18 & 20 \\
\hline Sobs & 46 & 32 & 33 \\
\hline $\mathbf{S}_{\text {chao2 }}$ & 48.98 & 40.5 & 36.33 \\
\hline $\mathbf{S}_{\text {Jack1 }}$ & 51.96 & 40.5 & 40.3 \\
\hline Completeness \% & $\mathbf{8 8 . 5}$ & $\mathbf{7 9 . 0}$ & $\mathbf{8 1 . 9}$ \\
\hline
\end{tabular}

interesting is the data emerging from the estimates of the richness and the completeness calculated using the $1 \mathrm{~km}^{2}$ cells of the UTM grid as sampling units. Such size could be very useful to study larger areas or to include lower precision data in the analysis and the completeness values did not differ significantly from the resulting estimates obtained using $100 \times 100$ m sampling units (plots). For the Roccamonfina area, in addition, even using increasing size cells as sampling units, the estimates do not vary significantly. This result can be taken into account whenever we have to choose the better grid resolution to draw atlases from non punctual data (e.g., literature data or observations with low location accuracy). The elaborations should follow, in this case, a reverse path: starting from a large sampling unit (e.g., a $10 \times 10 \mathrm{~km}$ cells UTM grid), decreasing the size of the sampling units and calculating the completeness for the study area. Since small size cells will have more probability to hold 'singletons' (unique presence data) for a bigger number of species, the used estimators will 

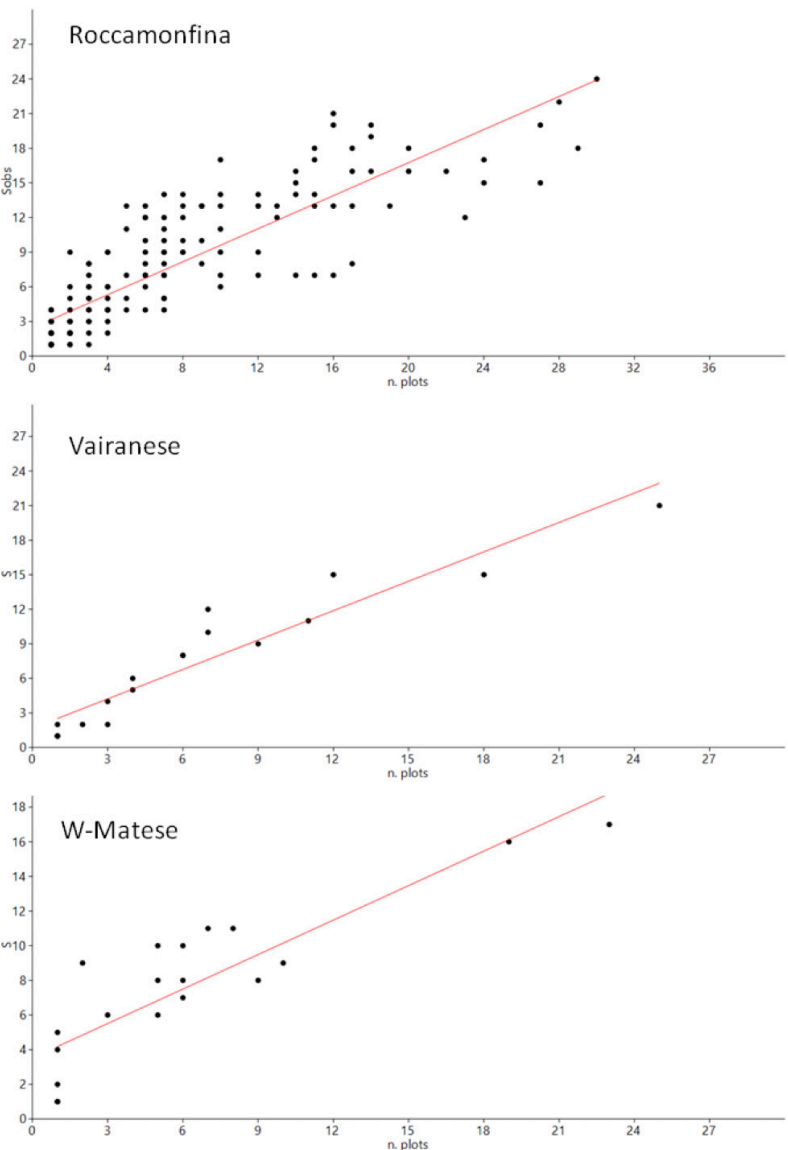

Figure 3. Correlation between number of plots and number of observed species for each of the $1 \mathrm{~km}^{2}$ cells.

give higher estimates of richness and, therefore, lower values of completeness.

For the same reason linked to the presence of singletons, in our study the number of sufficient studied squares (SSS) increases as their size become bigger. In the case of Roccamonfina area, using a grid of $9 \mathrm{~km}^{2}$ cells, a half of them are classified as SSS. The distribution of the completeness for a grid of $1 \mathrm{~km}^{2}$ cells (Table 4), on the other hand, is comparable for Roccamonfina and Vairanese, with more than $33 \%$ of the squares classified as SSS while for W-Matese area this value reaches only $25 \%$. To assess whether these rates represent a good result (i.e., the area is exhaustively well studied), we can refer to the choice of the limit of $65 \%$ to consider a cell as sufficiently studied. In Bruno et al. (2012) this completeness limit has been chosen to select a useful number of squares to perform further analysis. These authors, for all the four considered taxonomic groups, get lower portion of squares SSS compared to the portion we get for our studied areas. Nevertheless, the absolute number of SSS for both Vairanese and W-Matese areas

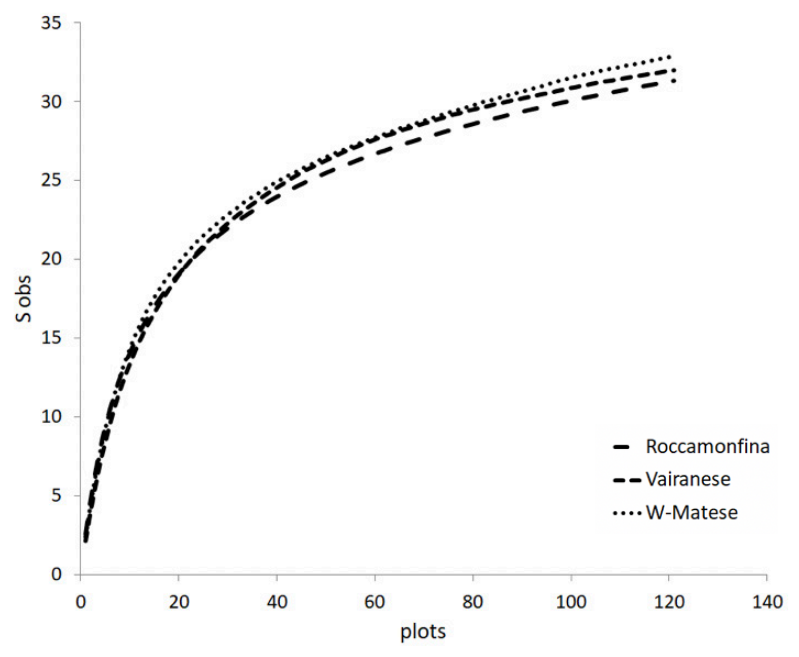

Figure 4. Rarefaction curves based on the number of sampling units (sample-based rarefaction curves) for the three study areas.

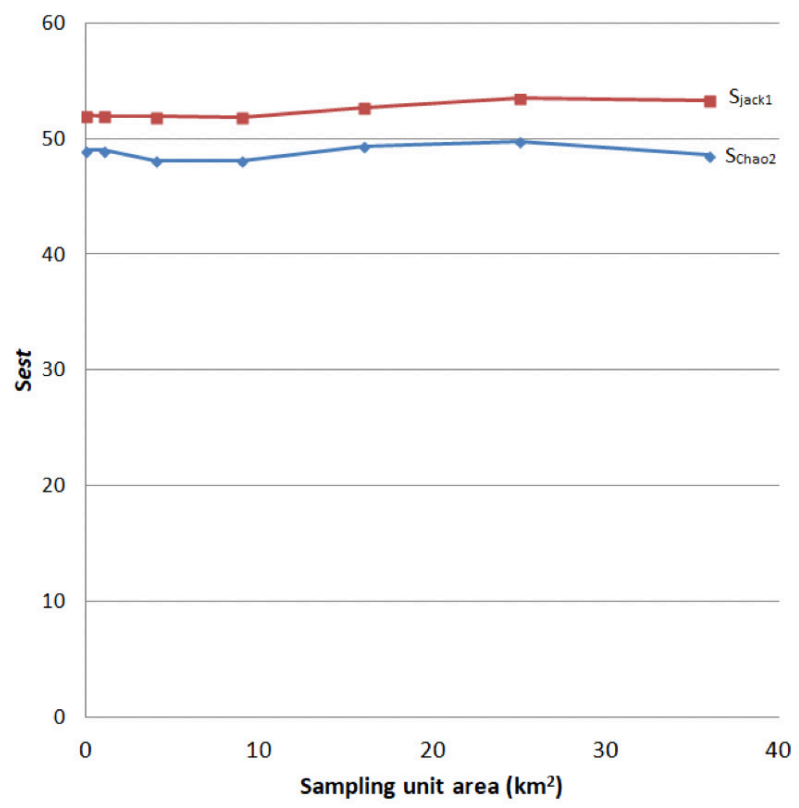

Figure 5. Completeness values using Chao2 e Jackknife1 estimators, using cells of different size $\left(100 \times 100 \mathrm{~m}, 1 \mathrm{~km}^{2}, 4 \mathrm{~km}^{2}, 9 \mathrm{~km}^{2}, 16 \mathrm{~km}^{2}\right.$, $25 \mathrm{~km}^{2}$, and $36 \mathrm{~km}^{2}$ ) as sampling units for the Roccamonfina area.

(respectively six and five squares) is too low and recall the need to continue the study in these two areas. The stratified analysis by habitat types underlines firstly what habitats need more studies or are less suitable for orchids. For example, agricultural habitats for Roccamonfina would need further sampling since their completeness is only 55\% (Table 6). It could be expected that, adding further sampling, the completeness would increase even without an increasing of the species 
Table 5. Levels of completeness values of the cells of different size, for the Roccamonfina area (n.e. = not evaluated).

\begin{tabular}{|c|c|c|c|c|c|c|c|c|c|c|c|c|}
\hline \multirow[b]{2}{*}{ C } & \multicolumn{2}{|c|}{$1 \mathrm{~km}^{2}$} & \multicolumn{2}{|c|}{$4 \mathrm{~km}^{2}$} & \multicolumn{2}{|c|}{$9 \mathrm{~km}^{2}$} & \multicolumn{2}{|c|}{$16 \mathrm{~km}^{2}$} & \multicolumn{2}{|c|}{$25 \mathrm{~km}^{2}$} & \multicolumn{2}{|c|}{$36 \mathrm{~km}^{2}$} \\
\hline & n. cells & $\%$ & n. cells & $\%$ & n. cells & $\%$ & n. cells & $\%$ & n. cells & $\%$ & n. cells & $\%$ \\
\hline n.e. & 84 & 51.5 & 23 & 37.7 & 10 & 16.4 & 5 & 22.7 & 3 & 20 & 1 & 9.1 \\
\hline $0-25$ & 3 & 1.8 & 1 & 1.6 & 0 & 0 & 0 & 0 & 0 & 0 & 0 & 0 \\
\hline $25-50$ & 5 & 3.1 & 4 & 6.6 & 5 & 8.2 & 1 & 4.5 & 1 & 6.7 & 0 & 0 \\
\hline $50-75$ & 35 & 21.5 & 14 & 23 & 6 & 9.8 & 7 & 31.8 & 4 & 26.7 & 2 & 18.2 \\
\hline 75-100 & 36 & 22.1 & 19 & 31.1 & 12 & 19.7 & 9 & 40.9 & 7 & 46.6 & 8 & 72.7 \\
\hline tot & 163 & & 61 & & 33 & & 22 & & 15 & & 11 & \\
\hline SSS & 58 & 35.6 & 28 & 45.9 & 17 & 51.5 & 11 & 50 & 9 & 60 & 9 & 81.8 \\
\hline
\end{tabular}

Table 6. Completeness values of the main habitats in the three areas.

\begin{tabular}{|c|c|c|c|c|c|}
\hline \multicolumn{6}{|c|}{ Roccamonfina } \\
\hline Habitats & $\mathrm{S}_{\text {obs }}$ & Plots & $\mathrm{S}_{\text {chao2 }}$ & $\mathrm{S}_{\text {Jack1 }}$ & C \% \\
\hline Artificial (incl. Road verges) & 25 & 50 & 28.9 & 33.8 & 73.9 \\
\hline Agriculture & 11 & 18 & 20.0 & 16.7 & 55.0 \\
\hline Open habitats & 33 & 158 & 36.5 & 40.9 & 80.6 \\
\hline Broadleaved woodlands (excl. Chestnut woods) & 25 & 82 & 27.1 & 30.9 & 80.9 \\
\hline Chestnut coppices & 18 & 62 & 19.0 & 21.0 & 85.9 \\
\hline Chestnut orchards & 38 & 839 & 44.0 & 44.0 & 86.4 \\
\hline \multicolumn{6}{|c|}{ Vairanese } \\
\hline Habitats & $\mathrm{S}_{\text {obs }}$ & Plots & $\mathrm{S}_{\text {Chao2 } 2}$ & $\mathrm{~S}_{\text {Jack1 }}$ & C $\%$ \\
\hline Open habitats & 26 & 89 & 26.5 & 29.0 & 89.8 \\
\hline Broadleaved woodlands & 24 & 33 & 42.0 & 35.6 & 57.1 \\
\hline Evergreen woodlands & 6 & 8 & 6.7 & 8.6 & 69.6 \\
\hline \multicolumn{6}{|c|}{ W-Matese } \\
\hline Habitats & $\mathrm{S}_{\mathrm{obs}}$ & Plots & $\mathrm{S}_{\text {Chao } 2}$ & $\mathrm{~S}_{\text {Jack1 }}$ & C $\%$ \\
\hline Open habitats & 28 & 60 & 100.0 & 39.8 & 28.0 \\
\hline Broadleaved woodlands & 27 & 57 & 28.6 & 32.0 & 84.4 \\
\hline
\end{tabular}

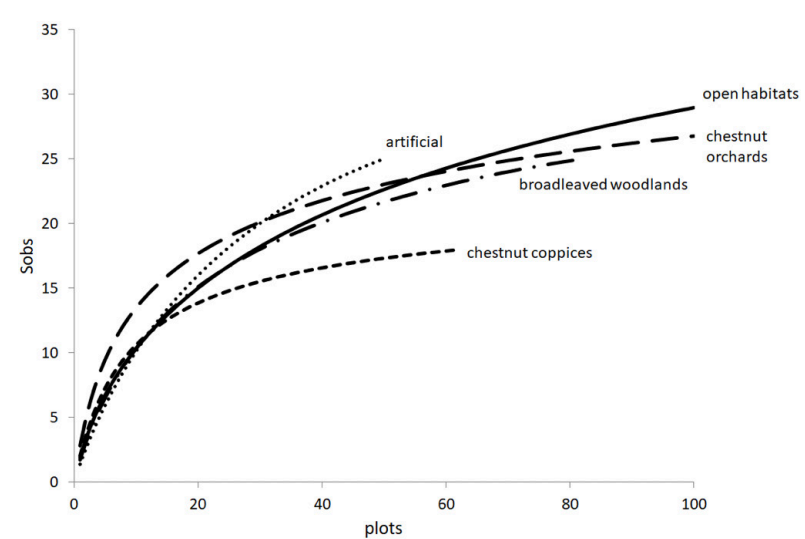

Figure 6. Rarefaction curves for the different habitats of the Roccamonfina area. richness. These habitats are in fact less suitable to host orchids as they are affected by frequent and strong ecological changes (e.g., soil tillage, switching to other crops, supply of nutrients). Such considerations could be made for the broadleaved woodlands of the Vairanese area, mostly represented by Holm oaks woodlands with very low light in the understory since orchids abundance is highly correlated to light regime (Djordjević \& Tsiftsis 2020; Hrivnák et al. 2020). On the contrary we expect that the low completeness value for the open habitats of the W-Matese area is due to a high theoretical richness of such habitats, not fully detected by the sampling activity. In other words, the sampling effort for the open habitats of the W-Matese area is still insufficient. 
Also, the rarefaction curves allow ecological considerations (Figure 6). The chestnut orchards represent an ecosystem made of a mosaic between woodlands and meadows, so they are a suitable habitat for the most heliophilous species as well as for the nemoral ones. This explains why their average species richness increases steeply even with a few plots (it is possible to observe more than 20 species in one plot). Nevertheless, on a larger scale, the richness of chestnut orchards is higher than the richness in open habitats only because of the higher area occupied by the former. When the curves are limited to 50 plots, surprisingly the richest habitats are the artificial areas. This result can be explained with the apophyte behavior of many orchids species (Adamowski 2006) and with the fact that we considered the roadsides as artificial habitats. Such environments can host many species characteristics of open habitats such as meadows and grasslands, and constitute important refuge areas for native species (Auestad et al. 2011).

Overall, the analysis of the three datasets allowed the sampling effort to be evaluated and gave useful indications to where and how to conduct the future researches. Moreover, some suggestions on the use of statistical tools to compare different study areas were given. For two areas (Roccamonfina and Vairanese), there is a sufficient level of knowledge of how the orchids richness is distributed, if we assume that a low completeness value in two squares out of three could be due to the lack of suitable habitats (i.e., urban areas or intensive agriculture areas) and to the difficult to locate a sufficient number of sampling units or plots. The squares with no data or with a lower completeness should be regarded as the highest priority areas for the future floristic research. Sampling these areas could increase the level of knowledge (i.e., the completeness value) and could lead to detect new species for the squares or for the studied area. The analysis of the floristic richness and the completeness of every habitat in a less known area would be very useful to prioritize, in each cell of a chosen grid, where to focus the research.

\section{CONCLUSIONS}

In conclusion, this study highlights that the quality of a floristic research can benefit from the evaluation of the completeness. Its calculation allows the creation of knowledge/ignorance maps for orchids at different scale using grids at different resolutions (e.g., from cells of $1 \mathrm{~km}^{2}$ for small islands and reserves to cells of 100 $\mathrm{km}^{2}$ for regions). A randomized and stratified sampling design would reduce the sampling bias, enable the use of abundance indices rather than presence/absence data and allow the investigation on the relation between species richness and environmental variables. It is often necessary, however, to take into account a large amount of data lacking accuracy or uniformity as is the case of data from literature or collected by different and sometimes occasional contributors (e.g., in citizen science projects).

In any case it is desirable in each modern floristic study and particularly orchids distribution study, a quantitative analysis of the work expressing the results not only as the total number of species observed and their distribution but focusing more on the sampling methods and on the distribution of the knowledge. Even if a sampling design avoiding preferential sampling would be desirable but not always possible (e.g., when using data from online platforms or literature), the proposed methods would help the authors to evaluate the sampling effort, identify the less studied areas or postpone the publication of their checklists and atlases until an acceptable level of exhaustivity, or completeness, would be reached.

\section{REFERENCES}

Adamowski, W. (2006). Expansion of native orchids in anthropogenous habitats. Polish Botanical Studies 22: 35-44.

Archer, M.E. (2019). Using non-parametric statistical analysis to estimate the numbers of solitary wasp and bee species (Hymenoptera: Aculeata) at study sites. Entomologist's Monthly Magazine 155(4): 263-270. https://doi.org/10.31184/M00138908.1554.3953

Asase, A. \& A.T. Peterson (2016). Completeness of digital accessible knowledge of the plants of Ghana. Biodiversity Informatics 11: 1-11. https://doi.org/10.17161/bi.v11i1.5860

Auestad, I., K. Rydgren \& I. Austad (2011). Road verges: potential refuges for declining grassland species despite remnant vegetation dynamics. Annales Botanici Fennici 48: 289-303. https://doi. org/10.5735/085.048.0401

Aung, Y.L., A.T. Mu, M.H. Aung, Q. Liu \& X. Jin (2020). An annotated checklist of Myanmar orchid flora. PhytoKeys 138: 49-112. https:// doi.org/10.3897/phytokeys.138.36144

Brose, U., N.D. Martinez \& R.J. Williams (2003). Estimating species richness: sensitivity to sample coverage and insensitivity to spatial patterns. Ecology 84(9): 2364-2377. https://doi.org/10.1890/020558

Bruno, D., D. Sánchez-Fernández, A. Millán, R.M. Ros, P. SánchezGómez \& J. Velasco (2012). Assessing the quality and usefulness of different taxonomic groups inventories in a semiarid Mediterranean region. Biodiversity and Conservation 21(6): 1561-1575. https:// doi.org/10.1007/s10531-012-0263-9

Chao, A. \& C.H. Chiu (2016). Species richness: estimation and comparison, pp 1-26. In: Balakrishnan, N., T. Colton, B. Everitt, W. Piegorsch, F. Ruggeri \& J. Teugels (eds). Wiley StatsRef: statistics reference on-line. John Wiley \& Sons, Hoboken, New Jersey. https:// doi.org/10.1002/9781118445112.stat03432.pub2

Colwell, R.K. (2013). EstimateS: Statistical estimation of species richness and shared species from samples. Version 9 and earlier. 
User's Guide and application. http://purl.oclc.org/estimates/ Accessed on 1 March 2020.

Crain, B.J. \& M. Fernández (2020). Biogeographical analyses to facilitate targeted conservation of orchid diversity hotspots in Costa Rica. Diversity and Distributions 26: 856-866. https://doi. org/10.1111/ddi.13062

Cribb, P.J., S.P. Kell, K.W. Dixon \& R.L. Barrett (2003). Orchid Conservation: A global perspective, pp 1-25. In: Dixon, K.W., S.P. Kell, R.L. Barrett \& P.J. Cribb (eds). Orchid Conservation. Natural History Publicatons, Kota Kinabalu, Sabah.

Croce, A. (2012). Le Orchidaceae dei monti S. Angelo, Caievola, S Nicola (Vairano Patenora e Pietravairano, Caserta). Giros Notizie 49: 60-67.

Croce, A. \& R. Nazzaro (2012). The orchid Flora of Roccamonfina-foce Garigliano Regional Park. Journal Europäischer Orchideen 44(3): 509-583.

Croce, A. \& R. Nazzaro (2017). An atlas of orchids distribution in the Campania region (Italy), a citizen science project for the most charming plant family. Italian Botanist 4: 15-32. https://doi. org/10.3897/italianbotanist.4.14916

Djordjević, V. \& S. Tsiftsis (2020). The role of ecological factors in distribution and abundance of terrestrial orchids, pp 1-71. In: Merillon, J.\& H. Kodja (eds.). Orchids Phytochemistry, Biology and Horticulture. Reference Series in Phytochemistry, Springer International Publishing: Basel, Switzerland. https://doi. org/10.1007/978-3-030-11257-8

Dressler, R.L. (1981). The orchids: natural history and classification Harvard University Press, Cambridge, MA, USA, 332pp. https://doi. org/10.2307/1219717

Efimov, P.G. (2020). Orchids of Russia: annotated checklist and geographic distribution. Nature Conservation Research 5(Suppl. 1): 1-18. https://doi.org/10.24189/ncr.2020.018

Frangini, G., R. Romolini, F. Sodi, M. Bisti, L. Forbicioni, M.A. Rusci \& G. Cortesi (2019). Orchidee dell'isola di Gorgona (Arcipelago Toscano). Giros Orchidee Spontanee d'Europa 62(1): 17-31.

Galesi, R. \& R. Lorenz (2010). Le Orchidaceae della Riserva Naturale Orientata "Oasi faunistica di Vendicari (Sicilia sud-orientale). Journal Europäischer Orchideen 42(1): 149-166.

García Márquez, J.R., C.F. Dormann, J.H. Sommer, M. Schmidt, A. Thiombiano, S.S. Da, C. Chatelain, S. Dressler \& W. Barthlott (2012). A methodological framework to quantify the spatial quality of biological databases. Biodiversity \& Ecology 4: 25-39. https://doi. org/10.7809/B-E.00057

Gotelli, N.J. \& R.K. Colwell (2001). Quantifying biodiversity: procedures and pitfalls in the measurement and comparison of species richness. Ecological Letters 4: 379-391. https://doi.org/10.1046/j.14610248.2001.00230.x

Gotelli, N.J. \& R.K. Colwell (2011). Estimating species richness, pp. 39-54. In: Magurran, A.E. \& B.J. McGill (eds.). Biological Diversity: Frontiers in Measurement and Assessment. Oxford University Press, Oxford, United Kingdom, 345 pp.

Hammer, Ø., D.A. Harper \& P.D. Ryan (2001). PAST: paleontological statistics software package for education and data analysis. Palaeontologia electronica 4(1): 9. https://palaeo-electronica. org/2001_1/past/issue1_01.htm Accessed on 01 March 2020.

Hortal, J., P.A.V. Borges \& C. Gaspar (2006). Evaluating the performance of species richness estimators: sensitivity to sample grain size. Journal of Animal Ecology 75: 274-287. https://doi.org/10.1111/ j.1365-2656.2006.01048.x

Hrivnák, M., M. Slezák, D. Galvánek, J. Vlčko, E. Belanová, V. Rízová, D. Senko \& R. Hrivnák (2020). Species Richness, Ecology, and Prediction of Orchids in Central Europe: Local-Scale Study. Diversity 12(4): 154. https://doi.org/10.3390/d12040154
Idohou, R., A. Arino, A. Assogbadjo, R.G. Kakai \& B. Sinsin (2015). Diversity of wild palms (Arecaceae) in the Republic of Benin: Finding the gaps in the national inventory combining field and digital accessible knowledge. Biodiversity Informatics 10: 45-55. https:// doi.org/10.17161/bi.v10i2.4914

Katopodi, E. \& S. Tsiftsis (2019). Contribution to the knowledge of the orchid flora of Lefkas island (Ionian Islands, Greece). Botanika Chronika 22: 127-143.

Marrero, Á., M. Claessens, D. González, C. Santiago, \& J. Claessens (2019). Chorological additions and distribution of the native orchids of Gran Canaria. Botánica Macaronésica 30: 65-88.

Martínez-Sanz, C., F. García-Criado, C.F. Alaez \& M.F. Alaez (2010). Assessment of richness estimation methods on macroinvertebrate communities of mountain ponds in Castilla y León (Spain). Annales de limnologie - International Journal of Limnology 46 (2): 101-110. https://doi.org/10.1051/limn/2010008

Mathew, J., \& K.V. George (2015). Checklist of Orchids of Kottavasal Hills in Achancoil Forests, southern Western Ghats, (Kollam, Kerala), India. Journal of Threatened Taxa 7(10): 7691-7696. https://doi. org/10.11609/JoTT.o3859.7691-6

Palmer, M.W. (1990). The estimation of species richness by extrapolation. Ecology 71(3): 1195-1198. https://doi. org/10.2307/1937387

Popovich, A. V., E.A. Averyanova \& L.M. Shagarov (2020). Orchids of the Black Sea coast of Krasnodarsky Krai (Russia): current state, new records, conservation. Nature Conservation Research 5(Suppl 1): 46-68. https://doi.org/ 10.24189/ncr.2020.047

Preston, F.W. (1962). The canonical distribution of commonness and rarity: Part I. Ecology 43(2): 185-215. https://doi. org/10.2307/1931976

QGIS Development Team (2019). QGIS Geographic Information System. Open Source Geospatial Foundation Project. http://qgis. osgeo.org/. Downloaded on 01 march 2020

Rocchini, D., J. Hortal, S. Lengyel, J.M. Lobo, A. Jimenez-Valverde , C. Ricotta, G. Bacaro \& A. Chiarucci (2011). Accounting for uncertainty when mapping species distributions: the need for maps of ignorance. Progress in Physical Geography 35(2): 211-226. https:// doi.org/10.1177/0309133311399491

Soberón, J.M., J.B. Llorente \& L. Oñate (2000). The use of specimenlabel databases for conservation purposes: an example using Mexican Papilionid and Pierid butterflies. Biodiversity and Conservation 9(10): 1441-1466. https://doi.org/10.1023/A:1008987010383

Soberón, J.M., R. Jiménez, J. Golubov \& P. Koleff (2007). Assessing completeness of biodiversity databases at different spatial scales. Ecography 30(1): 152-160. https://doi.org/10.1111/j.09067590.2007.04627.x

Ugland, K.I., J.S. Gray \& K.E. Ellingsen (2003). The speciesaccumulation curve and estimation of species richness. The Journal of Animal Ecology 72(5): 888-897. https://doi.org/10.1046/j.13652656.2003.00748.x

Vallet, J., M. Rambaud, L. Coquel, L. Poncet \& F. Hendoux (2012). Effort d'échantillonnage et atlas floristiques-exhaustivité des mailles et caractérisation des lacunes dans la connaissance. Comptes Rendus Biologies 335(12): 753-763. https://doi.org/10.1016/j. crvi.2012.11.005

WCSP (2019). World Checklist of Selected Plant Families. Facilitated by the Royal Botanic Gardens, Kew. http://wcsp.science.kew.org/ home.do Downloaded on 20 November 2020.

Weigelt, P., C. König \& H. Kreft (2020). GIFT-A global inventory of floras and traits for macroecology and biogeography. Journal of Biogeography 47(1): 16-43. https://doi.org/10.1111/jbi.13623

WILD 
Dr. John Noyes, Natural History Museum, London, UK

Dr. Albert G. Orr, Griffith University, Nathan, Australia

Dr. Sameer Padhye, Katholieke Universiteit Leuven, Belgium

Dr. Nancy van der Poorten, Toronto, Canada

Dr. Kareen Schnabel, NIWA, Wellington, New Zealand

Dr. R.M. Sharma, (Retd.) Scientist, Zoological Survey of India, Pune, India

Dr. Manju Siliwal, WILD, Coimbatore, Tamil Nadu, India

Dr. G.P. Sinha, Botanical Survey of India, Allahabad, India

Dr. K.A. Subramanian, Zoological Survey of India, New Alipore, Kolkata, India

Dr. P.M. Sureshan, Zoological Survey of India, Kozhikode, Kerala, India

Dr. R. Varatharajan, Manipur University, Imphal, Manipur, India

Dr. Eduard Vives, Museu de Ciències Naturals de Barcelona, Terrassa, Spain

Dr. James Young, Hong Kong Lepidopterists' Society, Hong Kong

Dr. R. Sundararaj, Institute of Wood Science \& Technology, Bengaluru, India

Dr. M. Nithyanandan, Environmental Department, La Ala Al Kuwait Real Estate. Co. K.S.C.,

Kuwait

Dr. Himender Bharti, Punjabi University, Punjab, India

Mr. Purnendu Roy, London, UK

Dr. Saito Motoki, The Butterfly Society of Japan, Tokyo, Japan

Dr. Sanjay Sondhi, TITLI TRUST, Kalpavriksh, Dehradun, India

Dr. Nguyen Thi Phuong Lien, Vietnam Academy of Science and Technology, Hanoi, Vietnam

Dr. Nitin Kulkarni, Tropical Research Institute, Jabalpur, India

Dr. Robin Wen Jiang Ngiam, National Parks Board, Singapore

Dr. Lional Monod, Natural History Museum of Geneva, Genève, Switzerland.

Dr. Asheesh Shivam, Nehru Gram Bharti University, Allahabad, India

Dr. Rosana Moreira da Rocha, Universidade Federal do Paraná, Curitiba, Brasi

Dr. Kurt R. Arnold, North Dakota State University, Saxony, Germany

Dr. James M. Carpenter, American Museum of Natural History, New York, USA

Dr. David M. Claborn, Missouri State University, Springfield, USA

Dr. Kareen Schnabel, Marine Biologist, Wellington, New Zealand

Dr. Amazonas Chagas Júnior, Universidade Federal de Mato Grosso, Cuiabá, Brasil

Mr. Monsoon Jyoti Gogoi, Assam University, Silchar, Assam, India

Dr. Heo Chong Chin, Universiti Teknologi MARA (UiTM), Selangor, Malaysia

Dr. R.J. Shiel, University of Adelaide, SA 5005, Australia

Dr. Siddharth Kulkarni, The George Washington University, Washington, USA

Dr. Priyadarsanan Dharma Rajan, ATREE, Bengaluru, India

Dr. Phil Alderslade, CSIRO Marine And Atmospheric Research, Hobart, Australia

Dr. John E.N. Veron, Coral Reef Research, Townsville, Australia

Dr. Daniel Whitmore, State Museum of Natural History Stuttgart, Rosenstein, Germany.

Dr. Yu-Feng Hsu, National Taiwan Normal University, Taipei City, Taiwan

Dr. Keith V. Wolfe, Antioch, California, USA

Dr. Siddharth Kulkarni, The Hormiga Lab, The George Washington University, Washington,

D.C., USA

Dr. Tomas Ditrich, Faculty of Education, University of South Bohemia in Ceske

Budejovice, Czech Republic

Dr. Mihaly Foldvari, Natural History Museum, University of Oslo, Norway

Dr. V.P. Uniyal, Wildlife Institute of India, Dehradun, Uttarakhand 248001, India

Dr. John T.D. Caleb, Zoological Survey of India, Kolkata, West Bengal, India

Dr. Priyadarsanan Dharma Rajan, Ashoka Trust for Research in Ecology and the Environment

(ATREE), Royal Enclave, Bangalore, Karnataka, India

\section{Fishes}

Dr. Neelesh Dahanukar, IISER, Pune, Maharashtra, India

Dr. Topiltzin Contreras MacBeath, Universidad Autónoma del estado de Morelos, México

Dr. Heok Hee Ng, National University of Singapore, Science Drive, Singapore

Dr. Rajeev Raghavan, St. Albert's College, Kochi, Kerala, India

Dr. Robert D. Sluka, Chiltern Gateway Project, A Rocha UK, Southall, Middlesex, UK

Dr. E. Vivekanandan, Central Marine Fisheries Research Institute, Chennai, India

Dr. Davor Zanella, University of Zagreb, Zagreb, Croatia

Dr. A. Biju Kumar, University of Kerala, Thiruvananthapuram, Kerala, India

Dr. Akhilesh K.V., ICAR-Central Marine Fisheries Research Institute, Mumbai Research

Centre, Mumbai, Maharashtra, India

Dr. J.A. Johnson, Wildlife Institute of India, Dehradun, Uttarakhand, India

Amphibians

Dr. Sushil K. Dutta, Indian Institute of Science, Bengaluru, Karnataka, India

Dr. Annemarie Ohler, Muséum national d'Histoire naturelle, Paris, France

\section{Reptiles}

Dr. Gernot Vogel, Heidelberg, Germany

Dr. Raju Vyas, Vadodara, Gujarat, India

Dr. Pritpal S. Soorae, Environment Agency, Abu Dubai, UAE.

Prof. Dr. Wayne J. Fuller, Near East University, Mersin, Turkey

Prof. Chandrashekher U. Rivonker, Goa University, Taleigao Plateau, Goa. India

Dr. S.R. Ganesh, Chennai Snake Park, Chennai, Tamil Nadu, India

Dr. Himansu Sekhar Das, Terrestrial \& Marine Biodiversity, Abu Dhabi, UAE
Birds

Dr. Hem Sagar Baral, Charles Sturt University, NSW Australia

Dr. Chris Bowden, Royal Society for the Protection of Birds, Sandy, UK

Dr. Priya Davidar, Pondicherry University, Kalapet, Puducherry, India

Dr. J.W. Duckworth, IUCN SSC, Bath, UK

Dr. Rajah Jayapal, SACON, Coimbatore, Tamil Nadu, India

Dr. Rajiv S. Kalsi, M.L.N. College, Yamuna Nagar, Haryana, India

Dr. V. Santharam, Rishi Valley Education Centre, Chittoor Dt., Andhra Pradesh, India

Dr. S. Balachandran, Bombay Natural History Society, Mumbai, India

Mr. J. Praveen, Bengaluru, India

Dr. C. Srinivasulu, Osmania University, Hyderabad, India

Dr. K.S. Gopi Sundar, International Crane Foundation, Baraboo, USA

Dr. Gombobaatar Sundev, Professor of Ornithology, Ulaanbaatar, Mongolia

Prof. Reuven Yosef, International Birding \& Research Centre, Eilat, Israel

Dr. Taej Mundkur, Wetlands International, Wageningen, The Netherlands

Dr. Carol Inskipp, Bishop Auckland Co., Durham, UK

Dr. Tim Inskipp, Bishop Auckland Co, Durham, UK

Dr. V. Gokula, National College, Tiruchirappalli, Tamil Nadu, India

Dr. Arkady Lelej, Russian Academy of Sciences, Vladivostok, Russia

Dr. Simon Dowell, Science Director, Chester Zoo, UK

Dr. Mário Gabriel Santiago dos Santos, Universidade de Trás-os-Montes e Alto Douro,

Quinta de Prados, Vila Real, Portugal

Dr. Grant Connette, Smithsonian Institution, Royal, VA, USA

Dr. M. Zafar-ul Islam, Prince Saud Al Faisal Wildlife Research Center, Taif, Saudi Arabia

Mammals

Dr. Giovanni Amori, CNR - Institute of Ecosystem Studies, Rome, Italy

Dr. Anwaruddin Chowdhury, Guwahati, India

Dr. David Mallon, Zoological Society of London, UK

Dr. Shomita Mukherjee, SACON, Coimbatore, Tamil Nadu, India

Dr. Angie Appel, Wild Cat Network, Germany

Dr. P.O. Nameer, Kerala Agricultural University, Thrissur, Kerala, India

Dr. Ian Redmond, UNEP Convention on Migratory Species, Lansdown, UK

Dr. Heidi S. Riddle, Riddle's Elephant and Wildlife Sanctuary, Arkansas, USA

Dr. Karin Schwartz, George Mason University, Fairfax, Virginia.

Dr. Lala A.K. Singh, Bhubaneswar, Orissa, India

Dr. Mewa Singh, Mysore University, Mysore, India

Dr. Paul Racey, University of Exeter, Devon, UK

Dr. Honnavalli N. Kumara, SACON, Anaikatty P.O., Coimbatore, Tamil Nadu, India

Dr. Nishith Dharaiya, HNG University, Patan, Gujarat, India

Dr. Spartaco Gippoliti, Socio Onorario Società Italiana per la Storia della Fauna "Giuseppe

Altobello", Rome, Italy

Dr. Justus Joshua, Green Future Foundation, Tiruchirapalli, Tamil Nadu, India

Dr. H. Raghuram, The American College, Madurai, Tamil Nadu, India

Dr. Paul Bates, Harison Institute, Kent, UK

Dr. Jim Sanderson, Small Wild Cat Conservation Foundation, Hartford, USA

Dr. Dan Challender, University of Kent, Canterbury, UK

Dr. David Mallon, Manchester Metropolitan University, Derbyshire, UK

Dr. Brian L. Cypher, California State University-Stanislaus, Bakersfield, CA

Dr. S.S. Talmale, Zoological Survey of India, Pune, Maharashtra, India

Prof. Karan Bahadur Shah, Budhanilakantha Municipality, Kathmandu, Nepal

Dr. Susan Cheyne, Borneo Nature Foundation International, Palangkaraja, Indonesia

Dr. Hemanta Kafley, Wildlife Sciences, Tarleton State University, Texas, USA

\section{Other Disciplines}

Dr. Aniruddha Belsare, Columbia MO 65203, USA (Veterinary)

Dr. Mandar S. Paingankar, University of Pune, Pune, Maharashtra, India (Molecular)

Dr. Jack Tordoff, Critical Ecosystem Partnership Fund, Arlington, USA (Communities)

Dr. Ulrike Streicher, University of Oregon, Eugene, USA (Veterinary)

Dr. Hari Balasubramanian, EcoAdvisors, Nova Scotia, Canada (Communities)

Dr. Rayanna Hellem Santos Bezerra, Universidade Federal de Sergipe, São Cristóvão, Brazil

Dr. Jamie R. Wood, Landcare Research, Canterbury, New Zealand

Dr. Wendy Collinson-Jonker, Endangered Wildlife Trust, Gauteng, South Africa

Dr. Rajeshkumar G. Jani, Anand Agricultural University, Anand, Gujarat, India

Dr. O.N. Tiwari, Senior Scientist, ICAR-Indian Agricultural Research Institute (IARI), New

Delhi, India

Dr. L.D. Singla, Guru Angad Dev Veterinary and Animal Sciences University, Ludhiana, India

Dr. Rupika S. Rajakaruna, University of Peradeniya, Peradeniya, Sri Lanka

Dr. Bahar Baviskar, Wild-CER, Nagpur, Maharashtra 440013, India

Reviewers 2018-2020

Due to pausity of space, the list of reviewers for $2018-2020$ is available online.

The opinions expressed by the authors do not reflect the views of the Journal of Threatened Taxa, Wildlife Information Liaison Development Society, Zoo Outreach Organization, or any of the partners. The journal, the publisher, the host, and the partners are not responsible for the accuracy of the political boundaries shown in the maps by the authors.

Journal of Threatened Taxa is indexed/abstracted in Bibliography of Systematic Mycology, Biological Abstracts, BIOSIS Previews, CAB Abstracts, EBSCO, Google Scholar, Index Copernicus, Index Fungorum, JournalSeek, National Academy of Agricultural Sciences, NewJour, OCLC WorldCat, SCOPUS, Stanford University Libraries, Virtual Library of Biology, Zoological Records.

NAAS rating (India) 5.64
Print copies of the Journal are available at cost. Write to:

The Managing Editor, JoTT,

c/o Wildlife Information Liaison Development Society,

No. 12, Thiruvannamalai Nagar, Saravanampatti - Kalapatti Road,

Saravanampatti, Coimbatore, Tamil Nadu 641035, India

ravi@threatenedtaxa.org 


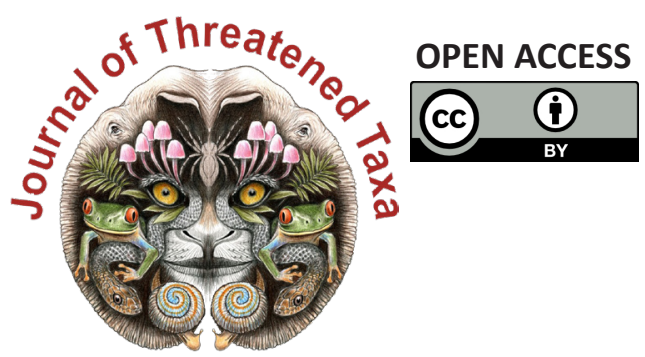

www.threatenedtaxa.org

The Journal of Threatened Taxa (JoTT) is dedicated to building evidence for conservation globally by publishing peer-reviewed articles online every month at a reasonably rapid rate at www.threatenedtaxa.org. All articles published in JoTT are registered under Creative Commons Attribution 4.0 International License unless otherwise mentioned. JoTT allows allows unrestricted use, reproduction, and distribution of articles in any medium by providing adequate credit to the author(s) and the source of publication.

\section{ISSN $0974-7907$ (Online) | ISSN $0974-7893$ (Print)}

\section{January 2022 | Vol. 14 | No. 1 | Pages: 20311-20538 \\ Date of Publication: 26 January 2022 (Online \& Print) DOI: 10.11609/jott.2022.14.1.20311-20538}

Articles

Estimating the completeness of orchid checklists and atlases: a case study from southern Italy

- Antonio Croce, Pp. 20311-20322

A floristic survey across three coniferous forests of Kashmir Himalaya, India - a checklist

- Ashaq Ahmad Dar, Akhtar Hussain Malik \& Narayanaswamy Parthasarathy, Pp. 20323-20345

Associations of butterflies across different forest types in Uttarakhand, western Himalaya, India: implications for conservation planning

- Arun Pratap Singh, Pp. 20346-20370

Comparison of bird diversity in protected and non-protected wetlands of western lowland of Nepal

- Jagan Nath Adhikari, Janak Raj Khatiwada, Dipendra Adhikari, Suman Sapkota, Bishnu Prasad Bhattarai, Deepak Rijal \& Lila Nath Sharma, Pp. 20371-20386

Local hunting practices and perceptions regarding the distribution and ecological role of the Large Flying Fox (Chiroptera: Pteropodidae: Pteropus vampyrus) in western Sarawak, Malaysian Borneo

- Jayasilan Mohd-Azlan, Joon Yee Yong, Nabila Norshuhadah Mohd Hazzrol, Philovenny Pengiran, Arianti Atong \& Sheema Abdul Aziz, Pp. 20387-20399

\section{Communications}

Macrolichens of Mathikettan Shola National Park, Western Ghats: a preliminary investigation with some new records

- Aswathi Anilkumar, Stephen Sequeira, Arun Christy \& S.M. Arsha, Pp. 20400-20405

New distribution record of globally threatened Ocean Turf Grass Halophila beccarii Ascherson, 1871 from the North Andaman Islands highlights the importance of seagrass exploratory surveys

- Swapnali Gole, Prasad Gaidhani, Srabani Bose, Anant Pande, Jeyaraj Antony Johnson \& Kuppusamy Sivakumar, Pp. 20406-20412

An inventory of new orchid (Orchidaceae) records from Kozhikode, Kerala, India - M. Sulaiman, C. Murugan \& M.U. Sharief, Pp. 20413-20425

Abundance and spatial distribution analyses of Stemonoporus moonii Thwaites (Dipterocarpaceae) - a critically endangered species endemic to Sri Lanka - K.A.M.R.P. Atapattu, H.D.D.C.K. Perera, H.S. Kathriarachchi \& A.R. Gunawardena, Pp. 20426-20432

Plant diversity of Point Calimere Wildlife Sanctuary and fodder species grazed by the Blackbuck Antilope cervicapra L.

- Ashutosh Kumar Upadhyay, A. Andrew Emmanuel, Ansa Sarah Varghese \&

D. Narasimhan, Pp. 20433-20443

Raptors observed (1983-2016) in National Chambal Gharial Sanctuary: semi-arid biogeographic region suggestions for parametric studies on ecological continuity in Khathiar-Gir Ecoregion, India

- L.A.K. Singh, R.K. Sharma \& Udayan Rao Pawar, Pp. 20444-20460

Nesting success of Sharpe's Longclaw (Macronyx sharpei Jackson, 1904) around the grasslands of lake Ol'bolossat Nyandarua, Kenya

- Hamisi Ann Risper, Charles M. Warui \& Peter Njoroge, Pp. 20461-20468

Population, distribution and diet composition of Smooth-coated Otter Lutrogale perspicillata Geoffroy, 1826 in Hosur and Dharmapuri Forest Divisions, India - Nagarajan Baskaran, Raman Sivaraj Sundarraj \& Raveendranathanpillai Sanil, Pp. 20469-20477

Utilization of home garden crops by primates and current status of human-primate interface at Galigamuwa Divisional Secretariat Division in Kegalle District, Sri Lanka

- Charmalie Anuradhie Dona Nahallage, Dahanakge Ayesha Madushani Dasanayake, Dilan Thisaru Hewamanna \& Dissanayakalage Tharaka Harshani Ananda, Pp. 2047820487
Revival of Eastern Swamp Deer Rucervus duvaucelii ranjitsinhi (Groves, 1982) in Manas National Park of Assam, India

- Nazrul Islam, Aftab Ahmed, Rathin Barman, Sanatan Deka, Bhaskar Choudhury, Prasanta Kumar Saikia \& Jyotishman Deka, Pp. 20488-20493

Trypanosoma evansi infection in a captive Indian Wolf Canis lupus pallipes - molecular diagnosis and therapy

- Manojita Dash, Sarat Kumar Sahu, Santosh Kumar Gupta, Niranjana Sahoo \& Debarat Mohapatra, Pp. 20494-20499

View Point

COVID-19 and civil unrest undoing steady gains in karst conservation and herpetological research in Myanmar, and an impediment to progress - Evan S.H. Quah, Lee L. Grismer, Perry L. Wood, Jr., Aung Lin \& Myint Kyaw Thura, Pp. 20500-20502

\section{Short Communications}

Morphological characterization and mt DNA barcode of a tiger moth species, Asota ficus (Fabricius, 1775) (Lepidoptera: Noctuoidea: Erebidae: Aganainae) from India - Aparna Sureshchandra Kalawate, K.P. Dinesh \& A. Shabnam, Pp. 20503-20510

Distribution of Smooth-coated Otters Lutrogale perspicillata (Mammalia: Carnivora: Mustelidae): in Ratnagiri, Maharashtra, India

- Swanand Patil \& Kranti Yardi, Pp. 20511-20516

Wildlife at the crossroads: wild animal road kills due to vehicular collision on a mountainous highway in northwestern Himalayan region

- Muzaffar A. Kichloo, Asha Sohil \& Neeraj Sharma, Pp. 20517-20522

Notes

Robiquetia gracilis (Lindl.) Garay-a new record to the flora of Anamalai Hills, Tami Nadu, India

- B. Subbaiyan, V. Ganesan, P.R. Nimal Kumar \& S. Thangaraj Panneerselvam, Pp. 20523-20525

Ipomoea laxiflora H.J. Chowdhery \& Debta (Convolvulaceae): new records for the Western Ghats and semiarid regions

- Sachin M. Patil, Ajit M. Vasava, Vinay M. Raole \& Kishore S. Rajput, Pp. 20526-20529

Counting the cost: high demand puts Bunium persicum (Boiss.) B.Fedtsch. in jeopardy

- Monika Sharma, Manisha Mathela, Rupali Sharma, Himanshu Bargali, Gurinderjit S Goraya \& Amit Kumar, Pp. 20530-20533

First record of Parasitic Jaeger Stercorarius parasiticus (Aves: Charadriiformes: Stercorariidae) from inland freshwater Inle Lake, Myanmar

- Sai Sein Lin Oo, Myint Kyaw, L.C.K. Yun, Min Zaw Tun, Yar Zar Lay Naung, Soe Naing Aye \& Swen C. Renner, Pp. 20534-20536

\section{Book Review}

Capparis of India

- V. Sampath Kumar, Pp. 20537-20538
Publisher \& Host
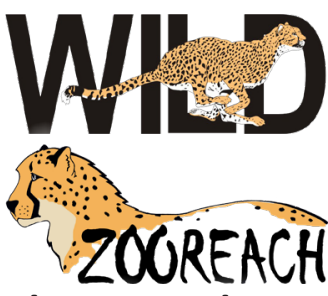

Threatened Taxa 